\title{
ANALISIS PERBEDAAN UJI KUALITAS AIR SUMUR DI DAERAH DATARAN TINGGI KOTA TOMOHON DAN DATARAN RENDAH KOTA MANADO BERDASARKAN PARAMETER FISIKA
}

\author{
${ }^{1}$ Puspithasari Morintoh \\ ${ }^{2}$ Jimmy F. Rumampuk \\ ${ }^{2}$ Fransiska Lintong
${ }^{1}$ Kandidat Skripsi Bagian Fisika Kedokteran Universitas Sam Ratulangi Manado
${ }^{2}$ Bagian Fisika Kedokteran Universitas Sam Ratulangi Manado
Email: pmorintoh094@yahoo.co.id

\begin{abstract}
Clean water is absolutely essential considering the activity of a society which is very dynamic. Therefore, the quality and quantity should be kept under control. Clean water that complied with health standards must be free from contamination and must fulfill the quality standards, one of which is the physical requirements. Drinking water that does not fulfill the quality standards can cause health problems. The form of the topography of an area can influence its ground water. This study aimed to analyze the differences between the quality of well water in the plateau area of Tomohon and the lowland area of Manado based on physical parameters. This study was conducted in the Laboratory of Physics BTKL Manado from November 2014 until January 2015. This was an observational analytical study with a cross sectional approach. There were 50 samples determined by purposive sampling. The data were analyzed by using SPSS 20 and Mann-Whitney U Test. The results showed no significant differences in water quality using parameters, as follows: taste, temperature, smell, and turbidity, with a p value $>0.05$ while the TDS and DHL parameters had a significant difference with a p value $<0.05$. Conclusion: There were no significant differences of water quality in taste, temperature, smell, and turbidity, while the TDS parameters and DHL have significant differences of water quality with a p value $<0.05$.
\end{abstract}

Keywords: water quality, plateau, lowland, physics parameters

\begin{abstract}
Abstrak: Keberadaan air bersih menjadi sangat penting mengingat aktivitas kehidupan masyarakat yang sangat dinamis. Oleh karena itu harus diperhatikan kualitas dan kuantitasnya.Air bersih yang memenuhi syarat kesehatan harus bebas dari pencemaran dan harus memenuhi standar kualitas:salah satunya adalah persyaratan fisik karena air minum yang tidak memenuhi standar kualitas dapat menimbulkan gangguan kesehatan. Bentuk topografi pada suatu daerah dapat mempengaruhi air tanah pada daerah tersebut. Penelitian ini bertujuan untuk menganalisis perbedaan kualitas air sumur di daerah dataran tinggi kota Tomohon dan dataran rendah kota Manado berdasarkan parameter fisika.Penelitian dilakukan di laboratorium fisika BTKL Manado pada bulan November 2014-Januari 2015. Metode pada penelitian ini yaitu observasional analitik dengan pendekatan potong lintang. Sampel ditentukan secara purposive sampling yang berjumlah 50 sampel. Data dianalisa menggunakan SPSS 20 dan uji Mann Whitney-U Test. Hasil penelitian menunjukkan tidak terdapat perbedaan signifikan pada kualitas air pada parameter rasa, suhu, bau dan kekeruhan dengan nilai $\mathrm{p}>0,05$ sedangkan parameter TDS dan DHL terdapat perbedaan yang signifikan dengan nilai $\mathrm{p}<0,05$. Simpulan: Tidak terdapat perbedaan kualitas air yang signifikan pada parameter rasa,suhu, bau dan kekeruhan sedangkan parameter TDS dan DHL terdapat perbedaan kualitas air yang signifikan dengan nilai $\mathrm{p}<0,05$.
\end{abstract}

Kata kunci: kualitas air, dataran tinggi, dataran rendah, parameter fisika

Air merupakan sumber daya alam yang diperlukan untuk hidup orang banyak, bahkan oleh semua makhluk hidup. ${ }^{1}$ Oleh karena itu harus diperhatikan kualitas dan 
kuantitasnya. Air bersih yang memenuhi syarat kesehatan harus bebas dari pencemaran, sedangkan air minum harus memenuhi standar yaitu persyaratan fisik, kimia dan biologis, karena air minum yang tidak memenuhi standar kualitas dapat menimbulkan gangguan kesehatan. ${ }^{2}$

Saat ini, proses produksi air bersih yang dapat diminum telah menjadi perhatian dunia untuk memenuhi peningkatan populasi dan kebutuhan air bersih yang melebihi persediaan sumber air minum konvensional. Lebih dari 1 miliar orang hidup tanpa persediaan air bersih dan sekitar 2,3 miliar orang (41\% penduduk dunia) hidup di daerah yang mengalami krisis air. $^{3}$ Selain itu, sekitar 10.000 penduduk di negara berkembang meninggal setiap harinya karena penyakit yang disebabkan minimnya air bersih dan sanitasi lingkungan. Lebih dari 100 juta penduduk Indonesia kekurangan akses terhadap air bersih. ${ }^{4}$

Berdasarkan data Riset Kesehatan Dasar 2013 hasil menunjukkan bahwa jenis sumber air untuk seluruh kebutuhan rumah tangga di Indonesia pada umumnya adalah sumur gali terlindung (29,2\%), sumur pompa (24,1\%), dan PDAM (19,7\%). Di perkotaan, lebih banyak rumah tangga yang menggunakan air dari sumur bor/pompa (32,9\%) dan air ledeng/PDAM (28,6\%), sedangkan di pedesaan lebih banyak yang menggunakan sumur gali terlindung (32,7\%). Untuk sumber air minum, rumah tangga di Indonesia menggunakan air kemasan, air isi ulang/depot air minum, air ledeng baik dari PDAM maupun membeli eceran, sumur bor/pompa, sumur terlindung, mata air (baik terlindung maupun tidak terlindung), penampungan air hujan dan air sungai/irigasi. ${ }^{5}$

Keberadaan air bersih menjadi sangat penting mengingat aktivitas kehidupan masyarakat yang sangat dinamis.Bentuk topografi pada suatu daerah dapat mempengaruhi air tanah pada daerah tersebut.Daerah dataran rendah, yang merupakan daerah yang cenderung lebih cepat berkembang dibandingkan daerah yang memiliki topografi lebih tinggi, sehingga frekuensi pengambilan air tanah relatif besar karena pada daerah ini perkembangan penduduk tumbuh pesat.Sedangkan daerah dataran tinggi, daerah ini terletak di lereng kaki gunung. Pada daerah ini tataguna lahan masih didominasi oleh hutan dan tidak ada perubahan lahan yang cukup signifikan sehingga air tanah lebih banyak meresap daripada mengalir. ${ }^{6}$

Dalam Peraturan Menteri Kesehatan RI (Permenkes RI) No.492/Menkes/Per/IV/2010 tentang Kualitas Air Minum disebutkan bahwa air minum harus memenuhi persyaratan kesehatan secara fisik, kimiadan mikrobiologi. Air minum yang dikonsumsi dikategorikan baik apabila memenuhi persyaratan kualitas fisik; yaitu tidak keruh, tidak berwarna, tidak berasa, tidak berbusa dan tidak berbau. ${ }^{5}$

Data Badan Pusat Statistik 2010 menunjukkan untuk Provinsi Sulawesi Utara terdapat 30,60\% yang belum memiliki akses air bersih. ${ }^{7}$ Kota Manado dengan jumlah penduduk 451.172 jiwa, yang menggunakan jasa pelanggan PDAM berjumlah 211.870 dan sisanya masih menggunakan air sumur untuk kebutuhan minum, mandi dan mencuci yang hampir tidak memenuhi standar kesehatan, ${ }^{8}$ sedangkan untuk Kota Tomohon dengan jumlah penduduk sebanyak 95.157 jiwa, karena air yang disalurkan tidak mengalir setiap hari sehingga banyak penduduk beralih ke sumur bor/pompa. ${ }^{9}$

Berdasarkan uraian diatas peneliti tertarik untuk melakukan penelitian tentang "Analisis Perbedaan Uji Kualitas Air Sumur di Daerah Dataran Tinggi Kota Tomohon dan Dataran Rendah Kota Manado Berdasarkan Parameter Fisika”

\section{METODE PENELITIAN}

Penelitian ini merupakan penelitian observasional dengan menggunakan desain potong lintang yang bersifat analitik. Penelitian dilakukan di laboratorium fisika BTKL Manado pada bulan November 2014-Januari 2015. Sampel ditentukan secara purposive sampling yang berjumlah 50 sampel. 
Pada penelitian ini, variabel terikat adalah kualitas air sumur sedangkan variabel bebas adalah uji parameter fisika.Prosedur penelitian yaitu dilakukan pengelompokkan air sumur yang terletak di daerah dataran tinggi diambil 25 sampel dan 25 sampel pada daerah dataran rendah. Kemudian dilakukan pengambilan sampel air sumur dan sampel dibawa ke laboratorium.

Alat dan bahan yang digunakan untuk pemeriksaan antara lain Turbidimeter,

\section{HASIL PENELITIAN}

Tabel 1. Hasil Statistik Nilai Suhu Dataran Tinggi dan Dataran Rendah

\begin{tabular}{ccccc}
\hline $\begin{array}{c}\text { Variabel } \\
\text { Suhu }\end{array}$ & $\min$ & $\max$ & mean & $\begin{array}{c}\text { Std. } \\
\text { deviasi }\end{array}$ \\
\hline $\begin{array}{c}\text { Dataran } \\
\text { Tinggi }\end{array}$ & 24,0 & 24,2 & 24,104 &, 0676 \\
$\begin{array}{c}\text { Dataran } \\
\text { Rendah }\end{array}$ & 24,0 & 24,2 & 24,100 &, 0707 \\
\hline
\end{tabular}

Tabel 2. Hasil Statistik Nilai Kekeruhan Pada Dataran Tinggi dan Dataran Rendah

\begin{tabular}{ccccc}
\hline $\begin{array}{c}\text { Variabel } \\
\text { Kekeruhan }\end{array}$ & $\min$ & $\max$ & mean & $\begin{array}{c}\text { Std. } \\
\text { deviasi }\end{array}$ \\
\hline $\begin{array}{c}\text { Dataran } \\
\text { Tinggi }\end{array}$ &, 05 & 2,00 &, 8140 &, 67028 \\
$\begin{array}{c}\text { Dataran } \\
\text { Rendah }\end{array}$ &, 05 & 4,00 &, 8720 &, 80533 \\
\hline
\end{tabular}

Termometer, Total Dissolved Solid (TDS), Konduktivitimeter dan Alat tulis menulis. Teknis analisis data yang digunakan pada penelitian ini berupa analisa univariat dan bivariat.Analisa univariat dilakukan untuk melihat distribusi frekuensi dari variabel dependent dan variabel independent. Analisis bivariat dilakukan untuk mengetahui hasil perbedaan antara dua variabel bebas. Analisis bivariat dianalisa dengan menggunakan uji Mann Whitney U.

Tabel 3. Hasil Statistik Nilai TDS Pada Dataran Tinggi dan Dataran Rendah

\begin{tabular}{ccccc}
\hline $\begin{array}{c}\text { Variabel } \\
\text { TDS }\end{array}$ & min & max & mean & $\begin{array}{c}\text { Std. } \\
\text { deviasi }\end{array}$ \\
\hline $\begin{array}{c}\text { Dataran } \\
\text { Tinggi }\end{array}$ & 82 & 193 & 105,16 & 18,909 \\
$\begin{array}{c}\text { Dataran } \\
\text { Rendah }\end{array}$ & 91 & 229 & 139,20 & 36,961 \\
\hline
\end{tabular}

Tabel 4. Hasil Statistik Nilai Daya Hantar Listrik Pada Dataran Tinggi dan Dataran Rendah

\begin{tabular}{ccccc}
\hline $\begin{array}{c}\text { Variabel } \\
\text { DHL }\end{array}$ & min & max & mean & $\begin{array}{c}\text { Std. } \\
\text { deviasi }\end{array}$ \\
\hline $\begin{array}{c}\text { Dataran } \\
\text { Tinggi }\end{array}$ &, 2 &, 4 &, 208 &, 0400 \\
$\begin{array}{c}\text { Dataran } \\
\text { Rendah }\end{array}$ &, 2 &, 5 &, 284 &, 0850 \\
\hline
\end{tabular}

Tabel 5. Analisis Perbedaan Uji Kualitas Air Sumur diDataran Tinggi kotaTomohon dan Dataran Rendah kota Manado

\begin{tabular}{lllllll}
\hline Metode & Suhu & Kekeruhan & TDS & DHL & Rasa & Bau \\
& & & & & & \\
\hline Mann Whitney U & 303 & 304,5 & 141 & 130,5 & 312,5 & 312,5 \\
Z & $-0,204$ & $-0,167$ & $-3,409$ & $-4,236$ & 0,000 & 0,000 \\
Sig. & 0,839 & 0,868 & 0,001 & 0,000 & 1,000 & 1,000 \\
\hline
\end{tabular}

\section{BAHASAN}

Berdasarkan hasil penelitian uji statistik, pada analisa univariat didapatkan hasil bahwa terdapat 25 (50\%) lokasi sumur di daerah dataran tinggi Tomohon dan 25 (50\%) lokasi sumur di daerah dataran rendah Manado.

Hasil analisis menunjukkan bahwa nilai signifikansi pada variabel suhu adalah $\mathrm{p}=0$,839. Apabila dibandingkan dengan 
penggunaan $\alpha$ sebesar 5\% $(0,05)$, maka nilai probabilitas $\mathrm{p}=0,839>0,05$, sehingga dapat dikatakan bahwa tidak terdapat perbedaan uji kualitas air sumur berupa suhu di daerah dataran tinggi Tomohon dan dataran rendah kota Manado. Pada variabel kekeruhan diperoleh nilai $\mathrm{p}=$ 0,868. Apabila dibandingkan dengan penggunaan $\alpha$ sebesar 5\% $(0,05)$, maka nilai probabilitas $\mathrm{p}=0,868>0,05$, sehingga dapat dikatakan bahwa tidak terdapat perbedaan uji kualitas air sumur berupa tingkat kekeruhan di daerah dataran tinggi Tomohon dan dataran rendah kota Manado. Menurut penelitian yang dilakukan oleh Nujumuddin dalam tesisnya kekeruhan terjadi akibat sumberpencemar di lingkugan berupa jamban, kotoran binatang, sampah, sawah, sungai dan pantai. $^{10}$

Pada variabel TDS diperoleh nilai $\mathrm{p}=$ 0,001. Apabila dibandingkan dengan penggunaan $\alpha$ sebesar $5 \%(0,05)$, maka nilai probabilitas $\mathrm{p}=0,001<0,05$, sehingga dapat dikatakan bahwa terdapat perbedaan uji kualitas air sumur berupa tingkat TDS di daerah dataran tinggi Tomohon dan dataran rendah kota Manado. Pada variabel DHL diperoleh nilai $\mathrm{p}=0,000$. Apabila dibandingkan dengan penggunaan $\alpha$ sebesar 5\% $(0,05)$, maka nilai probabilitas $\mathrm{p}=0,000<0,05$, sehingga dapat dikatakan bahwa terdapat perbedaan uji kualitas air sumur berupa tingkat DHL di daerah dataran tinggi Tomohon dan dataran rendah kota Manado. Berdasarkan penelitian Arthana diketahui bahwa ada hubungan antara TDS dengan Daya Hantar Listrik (DHL) dimana keduanya mempunyai hubungan linear.Semakin tinggi TDS maka DHL juga semakin tinggi dan begitu pula sebaliknya.Total dissolved solid biasanya terdiri atas zat organik, garam anorganik dan gas terlarut. Selain itu TDS juga berhubungan dengan tingkat kesadahan dimana semakin tinggi TDS, maka kesadahan juga tinggi. ${ }^{11}$

Pada variabel rasa diperoleh nilai $\mathrm{p}=$ 1,000. Apabila dibandingkan dengan penggunaan $\alpha$ sebesar 5\% $(0,05)$, maka nilai probabilitas $\mathrm{p}=1,000>0,05$, sehingga dapat dikatakan bahwa tidak terdapat perbedaan uji kualitas air sumur berupa rasa di daerah dataran tinggi Tomohon dan dataran rendah kota Manado. Pada variabel bau diperoleh nilai $\mathrm{p}=1,000$. Apabila dibandingkan dengan penggunaan $\alpha$ sebesar $5 \% \quad(0,05)$, maka nilai probabilitas $\mathrm{p}=1,000>0,05$, sehingga dapat dikatakan bahwa tidak terdapat perbedaan uji kualitas air sumur berupa bau di daerah dataran tinggi Tomohon dan dataran rendah kota Manado. Pada hasil penelitian Muhammad Desiandi menunjukkan bahwa air di kawasan Manunggal tidak berasa dan tidak berbau. Kepmenkes No. 907/2002 mensyaratkan air tidak berasa dan tidak berbau sehingga disimpulkan bahwa air memenuhi persyaratan kualitas air minum. Bau yang dimaksudkan dalam ketentuan Kepmenkes No.907/2002 harus dipahami secara benar oleh konsumen. Sebagian konsumen menganggap bau seperti kaporit yang ada dalam air mereka merupakan indikator air yang buruk sehingga mereka takut menggunakannya.Sebenarnya air yang berbau seperti kaporit tersebut adalah akibat sisa chlor yang ada dalam air. Masyarakat harus tahu bahwa dengan adanya bau seperti kaporit tersebut maka sebenarnya air yang ada pada mereka aman karena terhindar dari bakteri. ${ }^{11}$

Bentuk topografi pada suatu daerah dapat mempengaruhi air tanah pada daerah tersebut. Pada daerah dataran rendah frekuensi pengambilan air tanah relatif besar karena pada daerah ini perkembangan penduduk tumbuh pesat.Sedangkan daerah dataran tinggi, daerah ini terletak di lereng kaki gunung. Daerah lereng gunung ini dapat berfungsi sebagai daerah yang cukup potensial, karena pada daerah ini tataguna lahan masih didominasi oleh hutan dan tidak ada perubahan lahan yang cukup signifikan sehingga air tanah lebih banyak meresap daripada mengalir. ${ }^{6}$

Suhartono dalam skripsinya melaporkan kenaikan permukaan air laut, penurunan permukaan tanah dan pengambilan air tanah yang dilakukan secara terus-menerus menyebabkan 
majunya air laut kearah darat utamanya terjadi pada akuifer dalam akan bercampur dengan air tanah dan menyebabkan penurunan kualitas air tanah tersebut.

Pengambilan air tanah yang berlebihan menyebabkan banyaknya ruang kosong di dalam akuifer dan mengakibatkan tinggi muka air tanah lebih rendah dari pada permukaan air laut, perbedaan tinggi permukaaan air tanah dengan permukaan air laut ini menyebabkan air laut yang mengandung unsur garam seperti khlorida (Cl) merembes ke dalam air tanah sehingga menimbulkan pencemaran air tanah. ${ }^{12}$

Faktor penyebab lain dari kualitas air dapat ditinjau dari jenis sumur. Sumur gali menyediakan air yang berasal dari lapisan air tanah dangkal dari zone tidak jenuh, oleh karena itu dengan mudah kena kontaminasi melalui rembesan, sehingga berpotensi mengalami penurunan kualitas air. Kontaminasi paling umum adalah karena limpasan air dari sarana pembuangan kotoran manusia atau hewan, yang berasal dari septic tank WC yang kurang permanen. ${ }^{13}$ Sedangkan sumur bor dibuat dengan cara pengeboran lapisan air tanah yang lebih dalam sehingga sedikit dipengaruhi oleh kontaminasi. Jadi, dapat dikatakan bahwa sumur gali memiliki kualitas air yang kurang baik dibandingkan dengan sumur bor. ${ }^{4}$

\section{SIMPULAN}

1. Kualitas air yang diukur dengan parameter fisika yaitu rasa, bau, suhu, kekeruhan pada dataran tinggi kota Tomohon dan dataran rendah kota Manado tidak terdapat perbedaan uji kualitas air karena nilai yang diperoleh memenuhi dari kadar maksimum yang telah ditetapkan oleh Kepmenkes No.492/Menkes/Per/IV/2010.

2. Kualitas air yang diukur dengan parameter fisika yaitu TDS dan daya hantar listrik pada dataran tinggi kota Tomohon dan dataran rendah kota Manado terdapat perbedaan uji kualitas air karena nilai yang diperoleh tidak memenuhi dari kadar maksimum yang telah ditetapkan oleh Kepmenkes No.492/Menkes/Per/IV/2010.

\section{SARAN}

1. Dinas kesehatan perlu memberikan informasi kepada penduduk tentang air sumur yang mereka gunakan apakah layak untuk dikonsumsi atau tidak.

2. Perlu dilakukan penelitian selanjutnya yaitu analisis kualitas air berdasarkan parameter kimia dan mikrobiologi.

\section{DAFTAR PUSTAKA}

1. Ali A, Soemarno, Purnomo M. Kajian Kualitas Air dan Status Mutu Air Sungai Metro di Kecamatan Sukun Kota Malang. Jurnal Bumi Lestari. 2013;13:265-274.

2. Boekoesoe L. Tingkat Kualitas Bakteriologis Air Bersih di Desa Sosial Kecamatan Paguyaman Kabupaten Bualemo. Jurnal Inovasi. 2010;7:ISSN 1693-9034.

3. Dana GWY, Buana S. Analisis Perbandingan Pola Pasokan Air Bersih di Wilayah Kepulauan [Skripsi]. Teknik Perkapalan, Fakultas Teknologi Kelautan: ITS; 2011.

4. Parera MJ, Supit W, Rumampuk JF. Analisis Perbedaan Pada Uji Kualitas Air Sumur di Kelurahan Madidir Ure Kota Bitung Berdasarkan Parameter Fisika. Jurnal e-Biomedik (eBM). 2013;1:466-472.

5. Badan Penelitian dan Pengembangan Kesehatan. Riset Kesehatan Dasar (RISKESDAS) 2013. Kementrian Kesehatan Republik Indonesia; 2013.

6. Putranto TT, Kusuma KI. Permasalahan Air Tanah Pada Daerah Urban. Jurnal Teknik. 2009:30:ISSN 0852-1697.

7. Badan Pusat Statistik Kota Manado. 2012. Manado Dalam Angka 2012. Manado:Badan Pusat Statistik.

8. Dinas Kesehatan Sulawesi Utara, 2008. Profil Kabupaten/Kota Manado 2011. Sulawesi utara.

9. Badan Pusat Statistik Kota Tomohon. 2014. Statistik Daerah Kota Tomohon 2014. Tomohon: Badan Pusat Statistik.

10.Nujumuddin. Analisis Kualitas Air Sumur Gali di Kecamatan Sekarbela Kota Mataram - Nusa Tenggara Barat 
[Tesis]. Ilmu Lingkungan: Universitas Udayana; 2011.

11.Desiandi $M$, Sitorus JR, Hasyim $H$. Pemeriksaan Kualitas Air Minum Pada Daerah Persiapan Zona Air Minum PDAM Tirta Musi Palembang [Skripsi]. Palembang; 2009.

12.Suhartono E, Purwanto, Suripin. Faktor Penyebab Intrusi Air Laut Terhadap
Air Tanah Pada Akuifer Dalam Di Kota Semarang. Jurnal Teknik Sipil. 2013:18:ISNN76-87.

13.Marwati MN, Mardani NK, Sundra IK. Kualitas Air Sumur Gali Ditinjau Dari Kondisi Lingkungan Fisik Dan Perilaku Masyarakat Di Wilayah Puskesmas I Denpasar Selatan. Jurnal Ecotrophic. 2008:5:ISSN 1907-5626. 